\title{
Quality Of Work Life Factors Affects Employee Performance \& Employee Satisfaction
}

\author{
${ }^{1}$ Dr. Gayathri Band, ${ }^{2}$ Dr. Kanchan Naidu, ${ }^{3}$ Prof. Rijuta Joshi, \\ ${ }^{1}$ Shri Ramdeobaba College of Engineering and Management, Nagpur \\ ${ }^{2}$ Shri Ramdeobaba College of Engineering and Management, Nagpur \\ ${ }^{3}$ Shri Ramdeobaba College of Engineering and Management, Nagpur
}

Article History: Received:11 January 2021; Accepted: 27 February 2021; Published online: 5 April 2021

\begin{abstract}
Health is the best gift, peace is the best wealth. HR is a dynamic concept and so are the HR policies. Work Life Balance has gained tremendous importance since few years. Gone are the days of 9 to 5 . When we coin the concept of Business Process Outsourcing or BPO; the thing which strikes our minds is odd timings. It is vital that attention be given to work life balance. Enjoyment and achievement are the two major factors which relate to the overall success of a person in whole. A person works for family \& his own satisfaction. If the right balance is struck between work \& personal life, it can result into miracles. The study is undertaken to study the effects of quality of work life on the employee performance and employee satisfaction. The factors considered for study are work family conflict, organizational commitment, work exhaustion, work overload, fairness reward, participative decision making, performance enhancement. The findings show that the five factors (Participative Decision making, Work exhaustion, Work overload, Fairness of reward and Performance enhancement) of quality of work life effects the performance of the employees of the banking sector in Nagpur. The four factors (Performance enhancement, Organization Commitment, Fairness of reward and Work family conflict) of quality of work life effect the satisfaction of the employees of the banking sector in Nagpur.
\end{abstract}

KEYWORDS: Quality of work life, Employee performance, Employee Satisfaction

\section{INTRODUCTION:}

Health is the best gift, peace is the best wealth. HR is a dynamic concept and so are the HR policies. Work Life Balance has gained tremendous importance since few years. Gone are the days of 9 to 5 . When we coin the concept of Business Process Outsourcing or BPO; the thing which strikes our minds is odd timings. It is vital that attention be given to work life balance. Enjoyment and achievement are the two major factors which relate to the overall success of a person in whole. A person works for family \& his own satisfaction. If the right balance is struck between work \& personal life, it can result into miracles. The life of individual changes and so increases his productivity at work. Work Life Balance is a very important concept which needs attention of all the employers \& the employees.

Our life has four quadrants; Work, Family, Friends / Community and Self. To make one's life happy, it is very important in today's world to maintain a right balance between all the four quadrants. The four quadrants of life need to be handled. Work life balance varies over time often on a daily basis. The right balance today will be different tomorrow. There is no one size - fits all, balance we can strive for. Work life balance is different for each person. Certain problems faced by BPO employees are:

- $\quad$ Long Working hours

- Permanent Night Shifts

- Day shift and night shift (alternate week/month)

- High work targets

- Pressure at work

- Loss of identity

- Occupational Hazards

At the core of an effective work life balance are two main concepts. There are daily "Achievement" and "Enjoyment". They both are two sides of the same coin. The competition is increasing day by day. To prove one self and to achieve growth, a culture of more performance is coming into picture. Result is that they get overburdened with work. The talent supply market has become more performance driven. With the extended working hours, employees get less time to socialize. Trying to live a one sided life is the reason for many successful people that they are not happy or completely happy or nearly that happy they should be. It has been found that those who are able to strike the right balance not only enjoy their job but also return home with zeal and satisfaction.

\section{LITERATURE REVIEW}

The evolution of QWL began in late 1960s emphasizing the human dimensions of work that was focused on the quality of the relationship between the worker and the working environment (Rose et. al, 2006: 
61; Tabassum et. al, 2011: 19). QWL is a concept of behavioral scientist, and the term was first introduced by Davis at the Forty-Third American Assembly on the Changing World of Work at Columbia University's Arden House. The selected participants assembled there concluded in phrase was found the method of defining QWL varied and encompassed several different perspectives (Tabassum et. al, 2011: 19)

QWL is defined as the favorable conditions and environments of a workplace that support and promote employee satisfaction by providing them with rewards, job security, and growth opportunities. However, some researchers point out that Quality of Work Life (QWL) is not only related to personnel's well-being and their attitudes and feelings towards their job (Beaudoin \& Edgar, 2003) but also goes beyond job satisfaction (BoZnadh, 1998; Cheung \& Tang, 2009; Sirgy, Efraty, Siegel, \& Lee, 2001).

Locke (1976) defined employee satisfaction (often referred to as job satisfaction) as “a pleasurable or positive emotional state resulting from the appraisal of one's job or job experiences" (p. 1300). Employee needs and wants are satisfied when they perceive that rewards from the organization, including compensation, promotion, recognition, development, and meaningful work, meet or exceed their expectation (Hackman and Oldham, 1980). Largely, it appears that the main outcomes of an effective QWL program are improved working conditions for employees and greater organizational effectiveness for employers. (Adhikari Gautam, 2010). QWL positively facilitates the creation of a more flexible, loyal, and motivated workforce, and thereby determines the company's competitiveness.

\section{MATERIAL \& METHODS}

A study was designed to investigate the relationship between Quality of Work life of the employees and the Employee performance and if Quality of Work life effects the performance of the employees. Four factors under employee performance is considered. These four factors are reduced to one factor for further analysis. The four factors are Skills, Knowledge, Quality of work and Accountability. Each statement was rated on a 5-point Likert type scale, with high scores indicating strong support for that particular statement. A total of 300 bank employees from Nagpur have been considered. 175 from Private bank and 125 from Public bank have provided responses to these statements. Factor analysis (with principal components extraction) was employed to investigate whether these statements represent identifiable factors which are important criterion of Quality Work life to improve employee performance.

\section{HYPOTHESIS:}

H1: Employee performance is affected by the quality of work life.

H2: Employee satisfaction is affected by the quality of work life.

TOOLS \& TECHNIQUES USED: Regression analysis was used to find out if the employee performance is affected by the quality of work life. The factors considered or study under quality of work life is work family conflict, organizational commitment, work exhaustion, work overload, fairness reward, participative decision making, performance enhancement.

\section{RESULTS \& DISCUSSION}

1. Employee performance is affected by quality of work life. Model Summary

\begin{tabular}{|r|r|r|r|r|}
\hline Model & R & R Square & Adjusted R Square & Std. Error of the Estimate \\
\hline 1 & $.825^{\mathrm{a}}$ & .681 & .497 & .546 \\
& & & & \\
\hline
\end{tabular}

a. Predictors: (Constant), FAIRNESS_REWARD, ORG_COMMITMENT, WORK_EXHAUSTION, WORK_OVERLOAD, WORK_FAMILY_CONFLICT, PERFORMANCE_ENHANCE, PARTICIPATIVE_DECISION

Multiple $R$ is the correlation between the observed values of $Y$ and the values of $Y$ predicted by the multiple regression model. Therefore, large values of the multiple $R$ represent a large correlation between the predicted and observed values of the outcome which is 0.825 in the above result.

As such, multiple $R$ is a gauge of how well the model predicts the observed data. It follows that the resulting $R^{2}$ can be interpreted as the amount of variation in the outcome variable that is accounted for by the predictors in the model. We can say $68.1 \%$ of variation in Employee Performance is accounted for by the variables used in the regression model 


\begin{tabular}{|ll|r|r|r|r|r|}
\hline Model & & Sum of Squares & \multicolumn{1}{|c|}{ df } & Mean Square & F & \multicolumn{1}{c|}{ Sig. } \\
\hline 1 & Regression & 24.755 & 5 & 4.951 & 16.620 & $.000^{\mathrm{a}}$ \\
& Residual & 87.016 & 292 & .298 & & \\
& Total & 111.771 & 297 & & & \\
\hline
\end{tabular}

a. Predictors: (Constant), FAIRNESS_REWARD, ORG_COMMITMENT, WORK_EXHAUSTION, WORK_OVERLOAD, WORK_FAMILY_CONFLICT, PERFORMANCE_ENHANCE, PARTICIPATIVE_DECISION

b. Dependent Variable: PERFORMANCE

The ANOVA tests whether the model is significantly better at predicting the outcome than using the mean as a 'best guess. Specifically, the $F$-ratio represents the ratio of the improvement in prediction that results from fitting the model, relative to the inaccuracy that still exists in the model

The most important part of the table is the $F$-ratio, here $F$ is 16.620 , which is significant at $p<.001$ (because the value in the column labelled Sig. is less than .001). The regression model overall predicts Employee Performance significantly well.

\begin{tabular}{|c|c|c|c|c|c|c|}
\hline & & Coeff & ients ${ }^{\mathrm{a}}$ & & & \\
\hline & & & & Standardized & & \\
\hline 1 & & & & & & \\
\hline & ( (constart) & & . & & 2.055 & . 010 \\
\hline & \begin{tabular}{|l} 
WORK_FAMILY_CONFLICT \\
\end{tabular} & -.087 & .058 & -.145 & -1.509 & .136 \\
\hline & ORG_COMMITMENT & .015 & .075 & .017 & .202 & .840 \\
\hline & WORK_EXHAUSTION & -.230 & .052 & -.395 & -4.446 & .000 \\
\hline & WORK_OVERLOAD & -.211 & .079 & -.274 & -2.837 & .009 \\
\hline & FAIRNESS_REWARD & .190 & .067 & .244 & 2.667 & .006 \\
\hline & PARTICIPATIVE_DECISION & .464 & .083 & .464 & 4.775 & .000 \\
\hline & PERFORMANCE_ENHANCE & .143 & .079 & .143 & 1.542 & .051 \\
\hline
\end{tabular}

In multiple regression the model takes the form of equation and in that equation there are several unknown quantities (the $b$-values). The first part of the table gives us estimates for these $b$-values and these values indicate the individual contribution of each predictor to the model. If we replace the $b$-values in equation we find that we can define the model as follows:

$\mathrm{Y}($ Employee Performance $)=$

1.254 (Constant) -0.087 (Work_Family_Conflict) + 0.015 (Org_Commitment) - 0.230 (Work_Exhaustion) -

0.211 (Work_Overload) +0.190 (Fairness_Reward) + 0.464 (Participative_Decision) + 0.143

(Performance_Enhance)

The $b$-values tell us about the relationship between Job Satisfaction and each predictor. If the value is positive we can tell that there is a positive relationship between the predictor and the outcome, whereas a negative coefficient represents a negative relationship. The $b$-values tell us more than this, though. They tell us to what degree each predictor affects the outcome if the effects of all other predictors are held constant:

The $t$-statistic can be derived that tests whether a $b$-value is significantly different from 0 . It is easiest to conceptualize the $t$-tests as measures of whether the predictor is making a significant contribution to the model. Therefore, if the $t$-test associated with a $b$-value is significant (if the value in the column labelled Sig. is less than .05) then the predictor is making a significant contribution to the model. The smaller the value of Sig. (and the larger the value of $t$ ), the greater the contribution of that predictor. Hence looking at the t value we can say that Participative Decision making, Work exhaustion, Work overload, Fairness of reward and Performance enhancement are the largest contributors to the regression model apart from others.

The standardized beta values for Participative Decision making, Work exhaustion, Work overload, Fairness of reward and Performance enhancement are virtually higher than others $(0.464,0.395,0.274,0.244,0.143$ 
respectively) indicating that all the five variables have a comparable degree of importance in the model (this concurs with what the magnitude of the $t$-statistics told us).

\section{Employee satisfaction is affected by the quality of work life}

Model Summary

\begin{tabular}{|c|c|c|c|c|}
\hline Model & $\mathrm{R}$ & R Square & Adjusted R Square & Std. Error of the Estimate \\
\hline 1 & $.829^{\mathrm{a}}$ & .687 & .682 & .198 \\
\hline
\end{tabular}

a. Predictors: (Constant), FAIRNESS_REWARD, ORG_COMMITMENT, WORK_EXHAUSTION, WORK_OVERLOAD, WORK_FAMILY_CONFLICT, PERFORMANCE_ENHANCE, PARTICIPATIVE_DECISION

We can say $68.7 \%$ of variation in Employee Satisfaction is accounted for by the variables used in the regression model

ANOVA ${ }^{b}$

\begin{tabular}{|ll|r|r|r|r|r|}
\hline Model & & Sum of Squares & df & Mean Square & F & Sig. \\
\hline 1 & Regression & 25.291 & 5 & 5.058 & 128.386 & $.000^{\mathrm{a}}$ \\
& Residual & 11.504 & 292 & .039 & & \\
& Total & 36.795 & 297 & & & \\
\hline
\end{tabular}

a. Predictors: (Constant), FAIRNESS_REWARD, ORG_COMMITMENT, WORK_EXHAUSTION, WORK_OVERLOAD, WORK_FAMILY_CONFLICT, PERFORMANCE_ENHANCE, PARTICIPATIVE_DECISION

b. Dependent Variable: SATISFACTION

The most important part of the table is the $F$-ratio, here $F$ is 128.386 , which is significant at $p<.001$ (because the value in the column labelled Sig. is less than .001). The regression model overall predicts Employee Satisfaction significantly well.

\section{Coefficients $^{\mathrm{a}}$}

\begin{tabular}{|c|c|c|c|c|c|c|}
\hline & & \multicolumn{2}{|c|}{$\begin{array}{c}\text { Unstandardized } \\
\text { Coefficients }\end{array}$} & \multirow{2}{*}{$\begin{array}{c}\text { Standardized } \\
\text { Coefficients }\end{array}$} & \multirow[b]{2}{*}{$\mathrm{t}$} & \multirow[b]{2}{*}{ Sig. } \\
\hline \multicolumn{2}{|c|}{ Model } & $\mathrm{B}$ & Std. Error & & & \\
\hline \multirow[t]{8}{*}{1} & (Constant) & 7.408 & .052 & & .000 & 1.000 \\
\hline & WORK_FAMILY_CONFLICT & -.247 & .071 & .247 & 3.329 & .003 \\
\hline & ORG_COMMITMENT & .464 & .083 & .464 & 4.775 & .000 \\
\hline & WORK_EXHAUSTION & -.143 & .079 & .143 & 1.542 & .051 \\
\hline & WORK_OVERLOAD & -.038 & .076 & .038 & .503 & .616 \\
\hline & FAIRNESS_REWARD & .347 & .066 & .347 & 3.655 & .000 \\
\hline & PARTICIPATIVE_DECISION & .147 & .080 & .147 & 1.488 & .056 \\
\hline & PERFORMANCE_ENHANCE & .485 & .087 & .485 & 5.583 & .000 \\
\hline
\end{tabular}

a. Dependent Variable: SATISFACTION

If we replace the $b$-values in equation we find that we can define the model as follows:

$\mathrm{Y}$ (Employee Performance) $=7.408$ (Constant) -0.247 (Work_Family_Conflict) +0.464 (Org_Commitment) - 0.143 (Work_Exhaustion) - 0.038 (Work_Overload) + 0.347 (Fairness_Reward) +0.147 (Participative_Decision) +0.485 (Performance_Enhance) 
Looking at the $t$ value we can say that Performance enhancement, Organization Commitment, Fairness of Reward and Work Family Conflict are the largest contributors to the regression model apart from others.

The standardized beta values for Performance enhancement, Organization Commitment, Fairness of Reward and Work Family Conflict are virtually higher than others $(0.485,0.464,0.347,0.247$ respectively) indicating that all the four variables have a comparable degree of importance in the model (this concurs with what the magnitude of the $t$-statistics told us).

\section{CONCLUSION}

The five factors (Participative Decision making, Work exhaustion, Work overload, Fairness of reward and Performance enhancement) of quality of work life effects the performance of the employees of the banking sector in Nagpur.

The four factors (Performance enhancement, Organization Commitment, Fairness of reward and Work family conflict) of quality of work life effect the satisfaction of the employees of the banking sector in Nagpur.

\section{OTHER FINDINGS}

1. Work life balance is not gender biased.

It can be said that the concept of work life balance is not gender biased because $87 \%$ males and $89 \%$ females feel that work life balance exists.

\section{Travelling time}

Nagpur being a small city in terms of area, the travelling time is very less. Even if a person needs to travel $20 \mathrm{~km}$, it would hardly take half an hour as there is less traffic also.

\section{Alternative Shifts}

Some of the employees working in alternate shifts have reported to face certain health related issues pertaining to digestion. If the shift timings are kept alternate monthly with weekends off, it would be easy for the employees to maintain good health.

\section{Married where partner is also employed}

Out of 100 respondents, 74 are married. Out of 74, 65\% respondents' spouses are employed in other organizations. Out of this $65 \%, 67 \%$ married respondents feel that they are able to have work life balance.

\section{Quality time spent with family or friends}

The respondents are quite happy with the quality time spent with family or friends. $20 \%$ never miss out quality time. $24 \%$ miss out rarely. $56 \%$ of the respondents miss out quality time sometimes.

\section{Stress Management}

Music and entertainment is resorted to by $88 \%$ of the respondents as an effective tool for stress management. Others being yoga, meditation and dance.

\section{Stress related disease}

As the respondents are working on computers and have to take up calls as well, frequent headaches and hypertension are areas of concern. As it is a sitting job, employees tend to gain weight. So obesity can be said to be stress related issue.

\section{If employees have good work life balance, the organization will be effective.}

All the employees agree to it that if all the employees achieve the right balance between their work and life, the organization will be more successful and effective. This will be so as the employees' productivity will also increase with the satisfaction level at the personal front.

\section{Certain comments.}

Certain quotes which were received from the respondents clearly mentioned that they are happy with their organization and would like to continue. Not only this, they also mentioned that they are able to achieve work life balance. it is only sometimes, that because of certain issues at work they are not able to manage or enjoy their personal lives. 


\section{REFERENCES:}

1. ILO (2001) World Employment Report, 2001; ILO, Geneva

2. Mattingly, D. J. "Indian Call Centers: The Outsourcing of 'Good Jobs' for Women"

3. Centre for Global Justice, 2005 Conference Mattingly, D. J. "Indian Call Centers: The Outsourcing of 'Good Jobs' for Women", Centre for Global Justice, 2005 Conference Papers

4. NASSCOM Directory of Indian IT Enabled Services - 2002, NASSCOM, New Delhi

5. NASSCOM Indian ITES-BPO Industry Fact Sheet, ASSCOM, New Delhi, 2004

6. Ramesh, B. P. "Labour in Business Process Outsourcing: A Case Study of Call Centre Agents", NLI Research Studies Series No.51, V. V. Giri National Labour Institute, Noida, 2004

7. Singh, P. and A Pandey (2005) 'Women in Call Centers', Economic and Political Weekly, Vol.40, No.7, pp. $684-688$

8. Chavan S (2011), “A Critical Stud on Work Life Balance of BPO Employees in India”, International Conference on Technology \& Management

9. Adhikari, D.R \& Gautam, D.K. Labor legislations for improving quality of work life in Nepal. International Journal of Law and Management, 52(1), 2010, 40-53.

10. Hackman, J.R. and Oldham, G.R. (1980), Work Redesign, Addison-Wesley, Reading, MA.

11. Locke, E.E. (1976), “The nature and causes of job satisfaction”, in Dunnette, M.D. (Ed.), Handbook of Industrial and Organizational Psychology, Rand McNally, Chicago, IL, 1297-1349.

12. Beaudoin, L. E., \& Edgar, L. Hassles: Their importance to nurses' quality of work life. Nursing Economics, 21, 2003. 106-113

13. Sirgy, M. J., Efraty, D., Siegel, P., \& Lee, D. J. (2001). A new measure of quality of work life (QWL) based on need satisfaction and spillover theories. Social Indicators Research, 55, 241-302 